\section{Displaying a taxidermy rhinoceros in a museum: the Lisbon conservation approach}

\section{A exposição de um rinoceronte taxidermizado no museu: a abordagem de conservação adoptada em Lisboa}

CATARINA TEIXEIRA ${ }^{1 *}$

DAVID M.

WATERHOUSE ${ }^{2}$

LAURA MOURA ${ }^{1}$

PEDRO ANDRADE ${ }^{1}$

1. National Museum of Natural History and Science of the University of Lisbon / Museums of the University of Lisbon, PRISC, Rua da Escola Politécnica 56/58, 1250-102 Lisboa, Portugal 2. Norfolk Museums Service, Norwich Castle Study Centre, The Shirehall Market Avenue, Norwich, Norfolk NR1 3JQ, United Kindom

*cteixeirasilva@museus.ulisboa.pt

\section{KEYWORDS}

Horn

Replica

Replacement

Ethics

Preventive restoration firstly, we present a short overview of the problems in terms of the international context and the vulnerability of these specimens at museums, followed by a brief overview of the history of the Lisbon specimen. Finally, we detail and discuss our conservation, methodology and ethical approach to the removal and replacement of the specimen's original horns with replicas, based on Norfolk Museums Service's (UK) protocol and experience.

\section{Resumo}

A presente problemática em torno da exposição pública de um rinoceronte taxidermizado completo, existente em Lisboa, e os motivos que levaram à substituição do material de corno original são apresentados neste artigo. O exemplar em causa, do século XX, pertence atualmente ao Museu Nacional de História Natural e Ciência da Universidade de Lisboa (MUHNAC). As diversas advertências para os furtos de corno de rinoceronte em museus a decorrer por toda a Europa nas duas últimas décadas e a frequência de pedidos de empréstimo do espécime para exposições originaram um debate interno no MUHNAC. Neste artigo, em primeiro lugar, apresentamos um breve panorama da problemática em termos do contexto internacional e da vulnerabilidade destes espécimes em museus, seguido de um breve contexto histórico do espécime. Finalmente, detalhamos e discutimos a nossa abordagem de conservação, metodologia e ética na substituição do material de corno original por réplicas, baseado no protocolo e experiência dos museus de Norfolk em Inglaterra.

\section{PALAVRAS-CHAVE}

Corno

Réplica

Substituição

Ética

Restauro preventivo 


\section{Introduction}

In recent years, several specimens of rhinoceros in museum collections all over the world have been damaged or stolen due to the high market value of their horns, particularly in Asia. This has raised concerns in natural history museums, zoos, professional associations, and societies [1-2]. Some museums have replaced the horns of their specimens with replicas or removed them from public display to the safety of secure storage. Although newspaper articles about museum thefts abound, specialised literature discussing horns replacement with replicas is scarce. In this paper, we examine an intervention to remove the original horns of a fully mounted specimen of a black rhinoceros (Diceros bicornis), in all dimensions, but particularly from a conservation perspective. The specimen is part of the collections of the National Museum of Natural History and Science (MUHNAC), University of Lisbon. The intervention took place during autumn 2016.

The cultural and scientific heritage preserved by MUHNAC covers c. 400 years of history of teaching and research in Portugal. Its collections have multiple origins [3-5], now encompassing a total of 3.5 million objects covering natural history specimens, artistic, archaeological and ethnographic artefacts, scientific and medical instruments, as well as books, manuscripts, drawings, and maps. MUHNAC also has two botanic gardens - the Lisbon Botanic Garden (1878) and the Tropical Botanic Garden (1906) - and two historical astronomical observatories - the Ajuda Astronomical Observatory (1861) and the Polytechnic School Astronomical Observatory (1898) -, among other buildings of scientific and historical significance. In 2015, the Tropical Research Institute (IICT) - a Portuguese institution dating from the nineteenth century - was integrated with the University of Lisbon [6]. Its collections result from scientific expeditions to the former Portuguese colonies [7], particularly in Africa, and are presently curated and preserved by MUHNAC. The rhino specimen discussed in this paper is part of the IICT collections.

As we will explain, the idea of removing the original horns resulted from a series of loan demands for temporary exhibitions in Portugal, coupled with MUHNAC's intention to display the specimen in its longterm exhibition. Initially, the idea was far from consensual. Concerns were raised regarding the inevitable risk of damaging the specimen and loss of material. Doubts were also raised about the sequence of the procedure, and the materials and techniques to model the replicas, given that the internal structure and the nature of attachment of the horns were initially unknown. Perhaps more importantly, the idea of removing original parts from an object of cultural and scientific significance seemed against, not only the ethics and fundamental principles of conservation and restoration, but against everything that a museum is and does.
In order to reach the possibility of consensus and grounded decision-making, thorough interdisciplinary research coordinated by MUHNAC's conservators Catarina Teixeira and Laura Moura and taxidermist Pedro Andrade supported by Ana Campos, was developed. It covered similar interventions in other museums, relevant literature on methods and ethics, and the history of the rhino specimen itself, particularly its taxidermy mount. After considerable internal discussion involving the conservators, taxidermists, curators and the director, the decision was made to replace the original horns with replicas. In the absence of significant and detailed literature [8], this paper aims to provide a comprehensive narrative of the whole process, including the security context and the preliminary research, the ethical guidelines established, and the materials and methods used. Ultimately, we examine the broader implications of this case in the preservation of cultural heritage.

\section{The increasing vulnerability of rhino horns in museum collections}

Rhinoceros have been overhunted in the wild for many decades, resulting in significant population reduction and even the extinction of the Vietnamese Javan rhinoceros (Rhinoceros sondaicus annamiticus) [1]. In some cases, nature conservation programmes have successfully enlarged rhino populations, namely in some subspecies of black Rhinoceros (Diceros bicornis) [1]. However, unfortunately, poaching has considerably increased since 2008. In 2014, the number of poached rhinos increased more than tenfold since 2008 [9]. Ultimately, poaching is driven by pseudo-scientific claims from Asian traditional medicine that powdered rhinoceros horns - made from hard keratin proteins [10] - can treat and prevent cancer $[1,10]$, although demand for horns as artistic artefacts and collectible investments also plays a role [9]. The lack of rhinos in the wild, combined with the steep increase of the horns' market value, resulted in organised criminal groups targeting alternative sources, namely horns in museum collections, universities, antique dealers, private collections, and zoos. Some recent robberies have been violent [11]. Unlike rhinos in Africa, frequently protected by heavily armed guards, museums can be seen as relatively soft targets [12].

In order to better understand this context, we have compiled information about incidents in museums between 2002 and 2017, from reports and newspapers [1, 12-22]. It should be noted that many incidents are likely to remain unreported. Data are compiled in Figure 1, with thefts sorted per year/location and type of institution, covering mostly European museums. As shown, 2011 was the year with the largest number of reported thefts, with 21 cases in Europe. Before 2011, only nine cases were reported, mainly in African countries; after December 2011, 13 more cases were reported, all in Europe except a recent case in the USA. 


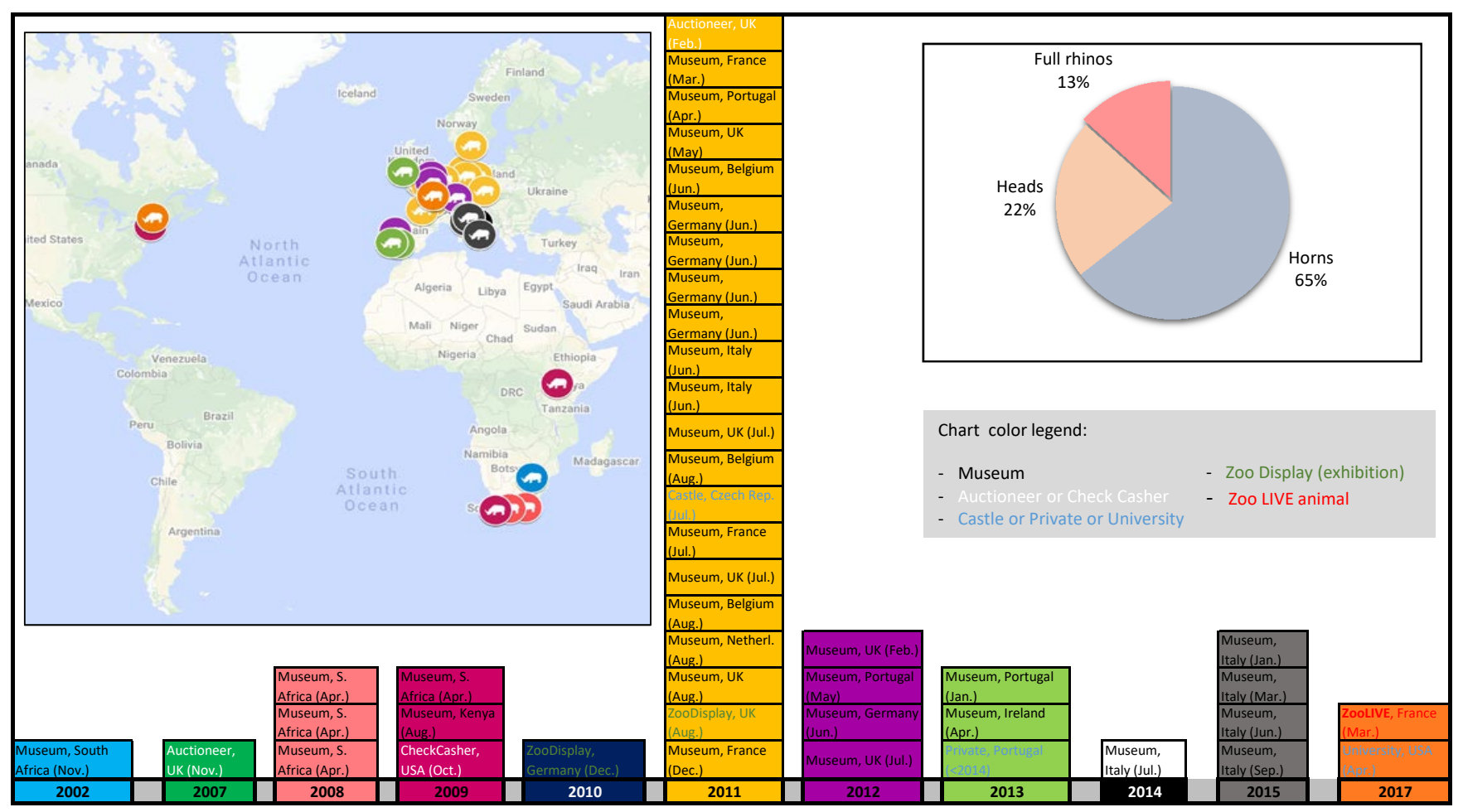

Figure 1. Number of rhino horns thefts per year, location and typology of stolen specimens, mainly reported in museums - for security reasons the institutions names have been omitted.

The post-2011 decrease in incidents is likely to result from public warnings, increased awareness, and the adoption of preventive measures to raise the security of museum specimens [1, 18].

We have also examined the typology of stolen specimens: $65 \%$ correspond to individual horns, $22 \%$ are trophy heads, and $13 \%$ are entire specimens of mounted rhinos. Individual horns can be more easily and discreetly stolen since no removal work is implied. At the same time, in strict prevention terms, loose horns are also easier to protect than mounted and larger specimens, which are normally on public display. In the case of trophy heads and full mounts, the horns are generally well-fixed and thieves have resorted to sawing and violent detachment, causing significant damage and loss. At Ipswich Museum (UK), the rhino horns were wrenched off a full mount [17]; in Rotterdam's Natural History Museum (The Netherlands) the horns were sawn off a trophy head [12] and the same happened in the Gothenburg Museum of Natural History (Sweden), but from a whole taxidermy specimen [16].

After 2011, Portuguese museums were also targeted in this wave of robberies. The first reported incident occurred at the Science Museum of the University of Coimbra. Two eighteenth-century individual horns were stolen from their permanent exhibition. The theft was prominent in the news [19], even internationally [1, 13-14, 20] and resulted in detentions by the Portuguese authorities and Interpol [23], along with the recovery of several stolen horns [24] (but unfortunately not those from Coimbra). In 2012, an individual horn was stolen from the Ethnographic and Zoological Museum of St. Tirso, in the north of Portugal
[19]. In 2013, five individual horns were stolen [24] from the exhibition of the Hunting Museum of Vila Viçosa, in the south of Portugal, after opening hours [19]. Before 2014, a robbery of 13 individual rhino horns was reported in a private collection in Mafra, north of Lisbon [19]. In private collections, the numbers of thefts could be even higher, but the information is scarce.

In this context, several recommendations have been published. The Humane Society International (HSI), an organisation working with animal protection issues around the world, suggests that, "museums or other public places that display preserved rhinos should, ideally, replace the horns with artificial replicas" [13]. Likewise, the UK-based Natural Sciences Collections Association (NatSCA) advises on a set of procedures for the care and safety of rhino horns in museums collections [25]. In one of the few papers on this subject, Paolo Viscardi also suggests that

for horns which are difficult to take off display, for example horns on large trophy heads or full taxidermy mounts, it may be worth considering removal of the horn by a conservation professional and replacement with replicas [I].

\section{The Lisbon black rhinoceros}

MUHNAC holds a full taxidermy mount of a female Black Rhinoceros Diceros bicornis (Inventory Nr. UL-IICTMAC-ZOO/34), as far as we know, the only specimen in a Portuguese public collection.

Once the specimen arrived in Portugal, its history 


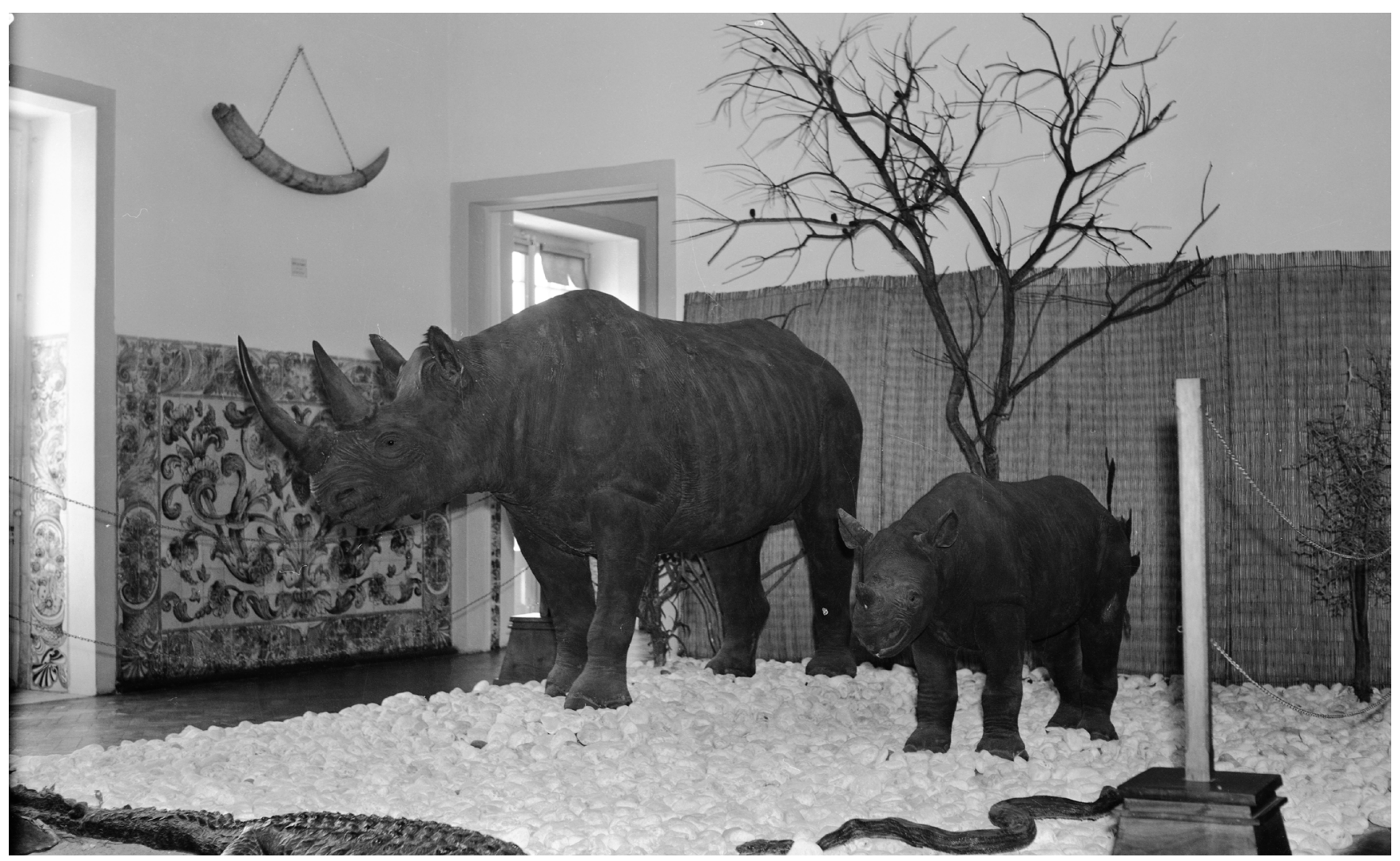

Figure 2. Undated photo of the adult female black rhinoceros and the juvenile on display at the JMAU (inv nr. PT/AMLSB/CMLSBAH/ PCSP/O04/NUN/O01441, Arquivo Municipal de Lisboa, Casa Fotográfica Garcia Nunes).

is already relatively well known. It was delivered by the Portuguese Overseas Agency (Agência Geral do Ultramar, AGU) to the Overseas Agriculture Museum and Garden (Jardim e Museu Agrícola do Ultramar, JMAU) in January 1957, along with a full mount of a juvenile specimen (inv. nr. UL-IICT-MAC-ZOO/30) [26-27]. According to the archives, its final destination should be the future Portuguese Overseas Museum (Museu Português do Ultramar) [28]. However, the two specimens remained at JMAU until 2016. This museum was created in 1906 to collect and display natural products of agricultural interest from the former Portuguese colonies, supporting tropical agricultural education. In 1916, it was located in Belém, Lisbon, in the main building - the Calheta palace - of the Tropical Botanic Garden, but official inauguration happened only in 1929 [29]. Visual sources depict both rhinos on display on the Calheta palace (Figure 2) [30-31]. The museum seems to have been closed to the public for long periods. Since 1978, visits could only be made by appointment and audiences were largely reduced to specialists [26]. The museum was closed in the early 1990 [ [32-33]. Today, both the garden and the palace are part of the University of Lisbon and its collections are managed by MUHNAC.

Our provenance research seems to confirm that the two specimens were collected in Angola, in 1954, near the Luengue river in the Cuando-Cubango region by Joséf J. Fenykövi (1891-?) [34]. Fenykövi himself reports having hunted a huge ("probably a world high record, given its $1.80 \mathrm{~m}$ " [35, p. 356]) rhinoceros female and baby, on that location [35, p. 353] and year [35, p. 324], adding that the adult specimen would be naturalized [35, p. 356] and "offered [...] to the Portuguese Government to be part of the Overseas Museum" [35, p. 357]. Fenykövi also refers to an English taxidermist from the British Museum (now the Natural History Museum, London), who had followed him on a previous expedition and shared his methods for measurement and skinning [35, p. 357]. Both specimens' taxidermy bases bear labels and inscriptions assigning the mounting to the Rowland Ward, Ltd., at the time based in London (Figure 3) - a renowned taxidermy company founded in England in 1870 [36]. More recent research conducted for this paper using the IICT and AGU historical archives confirmed that the Rowland Ward Company was definitely responsible for mounting these two rhinos both "offered by J. J. Fenykövi" [27].

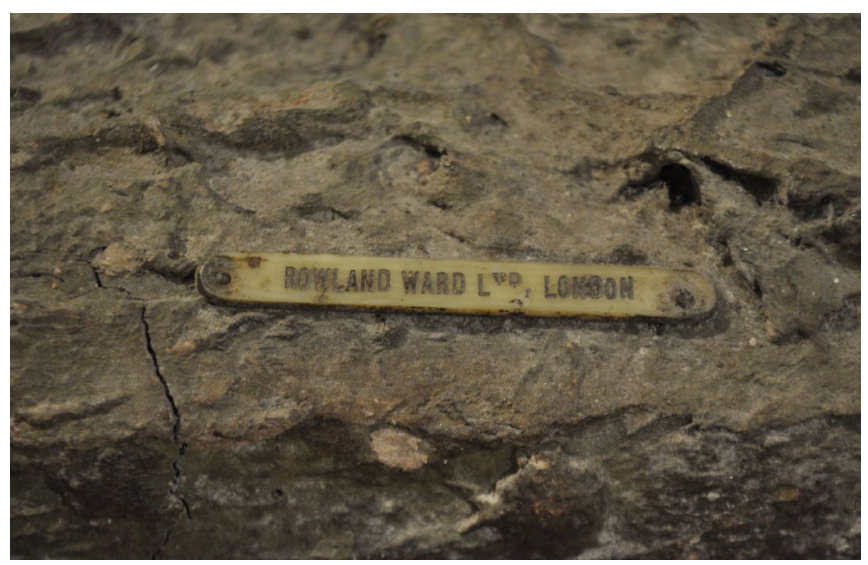

Figure 3. Label of the taxidermy company "Rowland Ward, Ltd, London" placed on the base of the adult specimen (photo: C. Gonçalves, IICT, 2012). 
After the museum closed, the two rhinos remained at the Calheta palace. They were only accessible to staff and researchers. A few temporary exhibitions organised between 2006 and 2014 [37-39] brought broader audiences to the palace and the collections in general, including the two rhino specimens. In the past 20 years, the adult specimen has been requested for several types of loan: i) for a temporary exhibition at the Torre de Belém (1992) [26, 40]; ii) to feature in an art installation film by Javier Téllez [41-42], recorded in the Miguel Bombarda Psychiatric Hospital (2010); and iii) for the temporary exhibition $360^{\circ}$ Ciência Descoberta at the Calouste Gulbenkian Foundation (2013) [43], which took place after the robbery wave in Europe and specific security measures were already addressed.

In 2016, the request for the loan of the adult rhino for the temporary exhibition Cidade Global - Lisboa no Renascimento (first at the National Museum of Ancient Art, in Lisbon, then at the Soares dos Reis National Museum, in Porto [44$45])$, raised the discussion to a more urgent level. These were two highly exposed and visited museums in Portugal. The security of the specimen and the safety of staff and public could have been at risk. At this point, replacing the horns with replicas became an option to consider as a preventive measure.

\section{Preserving rhino horns in museum collections: the problems and similar cases across Europe}

In scientific museums, particularly natural history museums, the use of replicas and didactic models has a long history and tradition. Apart from traditional skinmounts, taxidermists often build reproductions of animals and plants in resin and fibreglass for educational purposes. Replicas of footprints and entire specimens are often used in palaeontology for both display and research. More recently, 3-D imaging has been increasingly used in exhibitions and research alike. These replacement techniques are also part of the daily life of MUHNAC, namely, for conservation reasons (e.g. to reduce specimen handling), to replace what no longer exists (e.g. extinct species), or to avoid unsustainable or unethical collecting practices (e.g. killing animals or plants [46, p. 4]). Therefore, building replicas of rhino horns, was technically relatively easy - MUHNAC had the experience and resources. The problem was that, in this case, not only the reasons were different (safety and security) but the intervention was at direct odds with the concepts of integrity [47, p. 2] and authenticity [48-49].

Guidance by the cultural heritage sector at large (although not directly addressing the case of natural history heritage) proved important. Some charters and conventions for the protection of buildings, monuments and sites include recommendations for security reasons. For instance, the Australia Burra Charter mentions the possibility of removing parts of a site if it constitutes ensuring its ultimate security, preservation and protection [50]. More specifically, the European Confederation of Conservator-Restorers' Organisation (E.C.C.O.) states, in its Professional Guidelines: Code of Ethics, that a conservator-restorer should only remove original material from cultural heritage if it is indispensable to its preservation, by fully documenting it and preserving all the materials, including anything removed [47, p. 2]. In the same article, the exceptions for the decision of removal also includes interference with the historic and aesthetic values of the cultural heritage; however, security criteria could be an issue to ponder for exceptional situations as in the case described in this paper.

On the issue of replicas, E.C.C.O. indicates that reproductions are also a mean to consider for the preservation of cultural objects, especially when the public use seems to be incompatible with its preservation in the long-term [47, p. 2]. This could be more related to the display of an object in a fragile conservation condition. But, once again, in the case of specimens of endangered species, this is definitely a point for further discussion. A replica could be exhibited with the option of removing the original or part from display - note that larger trophies and full taxidermy mounts require space in storage -, whilst at the same time ensuring that the original is kept safely in storage and preserved for future use.

Perhaps more to the point in this case, inquiries for advice were posted to the NHCOLL-L forum [51], the largest forum of natural history collection professionals, particularly curators and conservators. Museums that were known to have replaced horns on taxidermy rhinos were also contacted [52-53]. Nigel Larkin (a natural history conservation specialist) provided literature, including a simple step-bystep guide of the reproduction process of rhino horns [54-55].

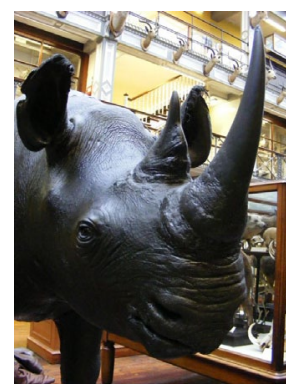

a

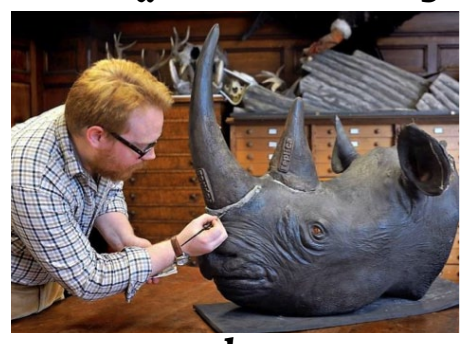

d

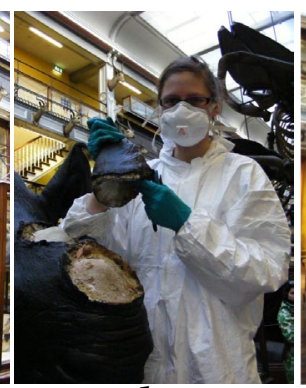

b

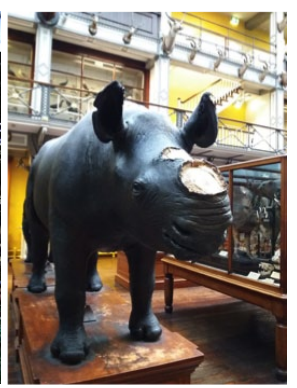

C
Figure 4. Images from the National Museum of Ireland mounted specimen until 2012 (a-c); David Waterhouse from Norfolk Museums Service with a rhino trophy head (d) and Nigel Larkin from Natural History Conservation (natural-history-conservation.com) installing replica rhino horns (e). 
Nigel Monaghan, the keeper of the Natural History Division of the National Museum of Ireland, Dublin, also provided useful information and images. At the time of contact, the museum in Dublin had decided to replace its rhino horns as a preventive measure [56], but their replicas were not yet completed [57]. However, the originals had been removed in 2012 and, from images, we could conclude that the Dublin specimen's modelling was different from that of the Lisbon specimen (Figure 4). The Dublin horns did not seem so strongly attached as ours and they were removed simply by detaching first the filler around the base, and then the spot tacks holding them to the skin [57]. Another museum that adopted horn replacements as a preventive measure was the Natural History Museum of Bern (Switzerland) [52], but information could not be obtained regarding the procedure.

Historical research on the Rowland Ward Company was paramount. The literature [58-59] provided important clues regarding the mounting (Figure 5):

Very large specimens would have a hollow torso, built like a barrel around the centre board, with wood wool bound over the top [...] cover it with strips of sacking ("scrim") dipped in plaster of Paris. When this was dry, papier maché would be added to create a malleable layer, allowing the skin to be manipulated from the outside to create folds and natural cavities [58, p. 94].
The Norfolk step-by-step procedure provided us clear information about requirements, techniques and materials. A step of major concern was the actual removal of the horns, a mechanical operation that had to be simultaneously forceful - to successfully extract the horns - and delicate - to produce as little damage as possible in the original material. The Norfolk procedure seemed comprehensive and thorough in its detail of requirements. Moreover, it respected the fundamental principles of conservation and restoration, both in the removal process and in the subsequent replicas, final retouching, and presentation. It guided the Lisbon intervention from the start to the end.

\section{MUNHAC's intervention: replacing the Lisbon rhino's horns with replicas}

\section{Establishing the intervention guidelines}

The analysis of the risks involved, coupled with research into the relevant literature, similar cases in European museums and the history of our collections enabled the Museum to reach a consensus and decide to go ahead with the replacement of the horns of our Diceros bicornis specimen.

Having the Norfolk intervention as a model, the MUHNAC conservation and taxidermy team began by

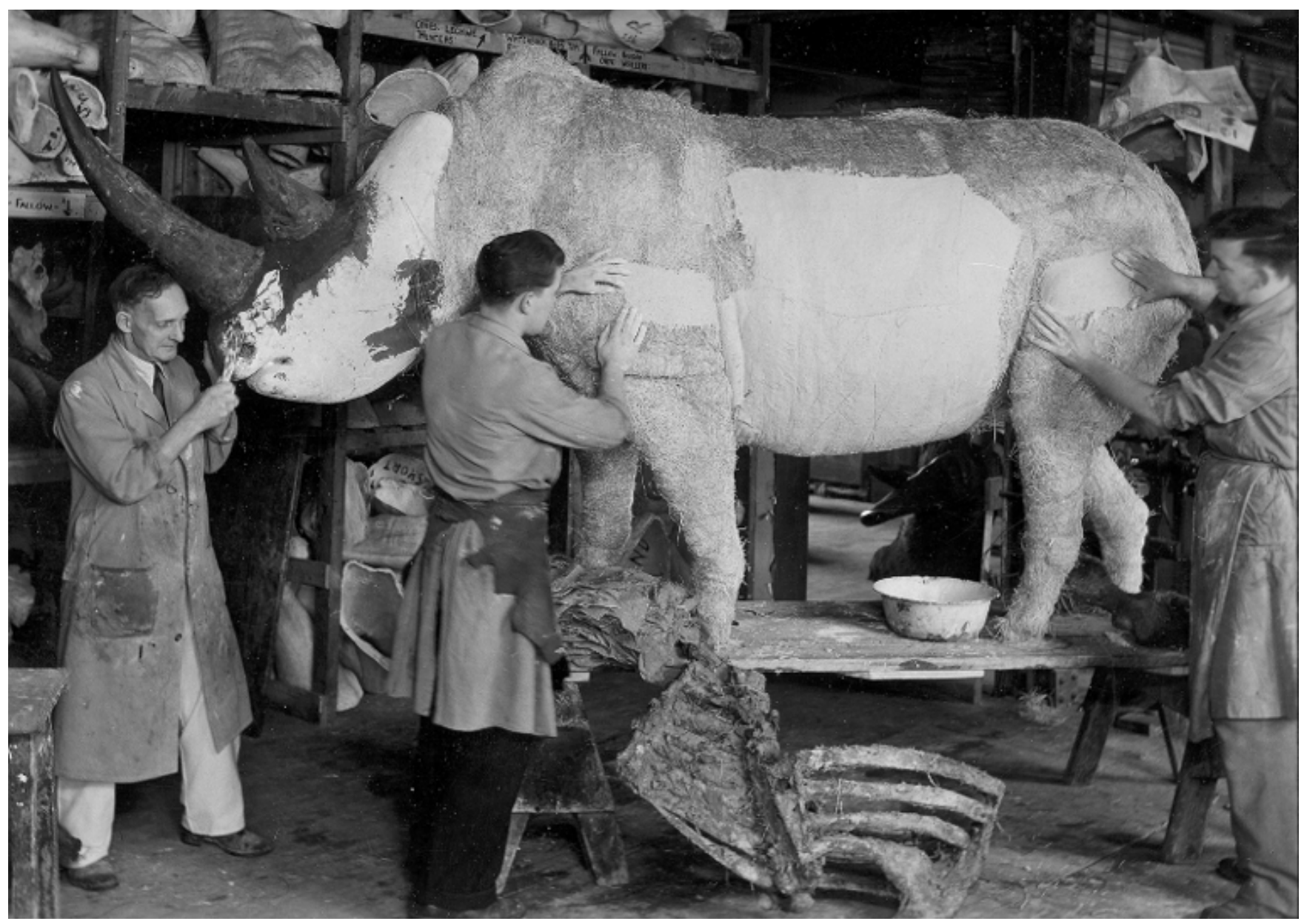

Figure 5. On the left, Alfred Taylor, foreman of the preparation of all large mammal taxidermy at Roland Ward's Company until 1958; in this picture assisted by Roy Hale and Eric Hare (photo: P. A. Morris Archives). 
establishing the general guidelines of the intervention in terms of general ethical principles, evaluation, security and safety, and documentation.

First, the intervention should ensure the least possible damage to both the surface and structure of the specimen and follow high conservation standards, namely the principles of minimal intervention, reversibility, and legibility. Second, the intervention should be done step-by-step, allowing close monitoring, reflection, and eventual adjustments to the methods or materials. Third, for security reasons the intervention should be performed discreetly and away from public view; all safety measures to guarantee the team protection from hazardous materials should be in place throughout the intervention. Fourth, the intervention should be fully documented in photos and video, before, during and after its conclusion. All fragments removed, no matter how small, were to be collected, registered, and further analysed. Finally, after removal, the original horns and fragments would be moved to the collections' store for purposes of future research and education, maintaining the same catalogue number and associated scientific data as the specimen they came from. Documentation resulting from the intervention should also be added to the specimen documentation in the MUHNAC's collection database.

\section{The removal procedure}

In Lisbon, the intervention - including research, horn removal, replica development and final attachment - took exactly three months, from 19 September to 19 December
2016. A multidisciplinary team from MUHNAC composed by conservators and taxidermists planned, conducted and evaluated this intervention. The rhino specimen was at Calheta palace, in Belém, and the taxidermy and conservation labs were located in MUHNAC.

The removal of the two horns lasted three days, between 19 and 21 September. Personal protection equipment, such as lab coats, chemical resistance gloves, dust and solvent masks, goggles and a mobile dust extractor, supported the intervention and assured the correct health and safety protection of staff involved. This was particularly important to reduce the risks of inhalation of toxic substances that could have been used in the preservation of the skin either in the field [35, p. 357], or later at mounting stage. Arsenical soap, mercury chloride [6061], powdered alum, corrosive sublimate, phenol, turpentine, are among the substances possibly present detailed by Morris [58, p. 89] and Ward [59, pp. 16-31].

From a technical perspective, the first stage of the removal process consisted of outlining the removal area, using metals scalpels and spatulas, and gently starting to mechanically detach the ring of painted plaster that covered the join of the horn with the skin, without scratching the two materials. The layer of plaster was not difficult to remove, unlike the inner filler (mortar). This initial step aimed at enabling a more confident search for the base of the horns, broadening the angle of view and the exposure of the attachment system to the wooden manikin head. A first set of four small rusty nails along the edge of the skin (with the shape of the base of the horns) were also removed,
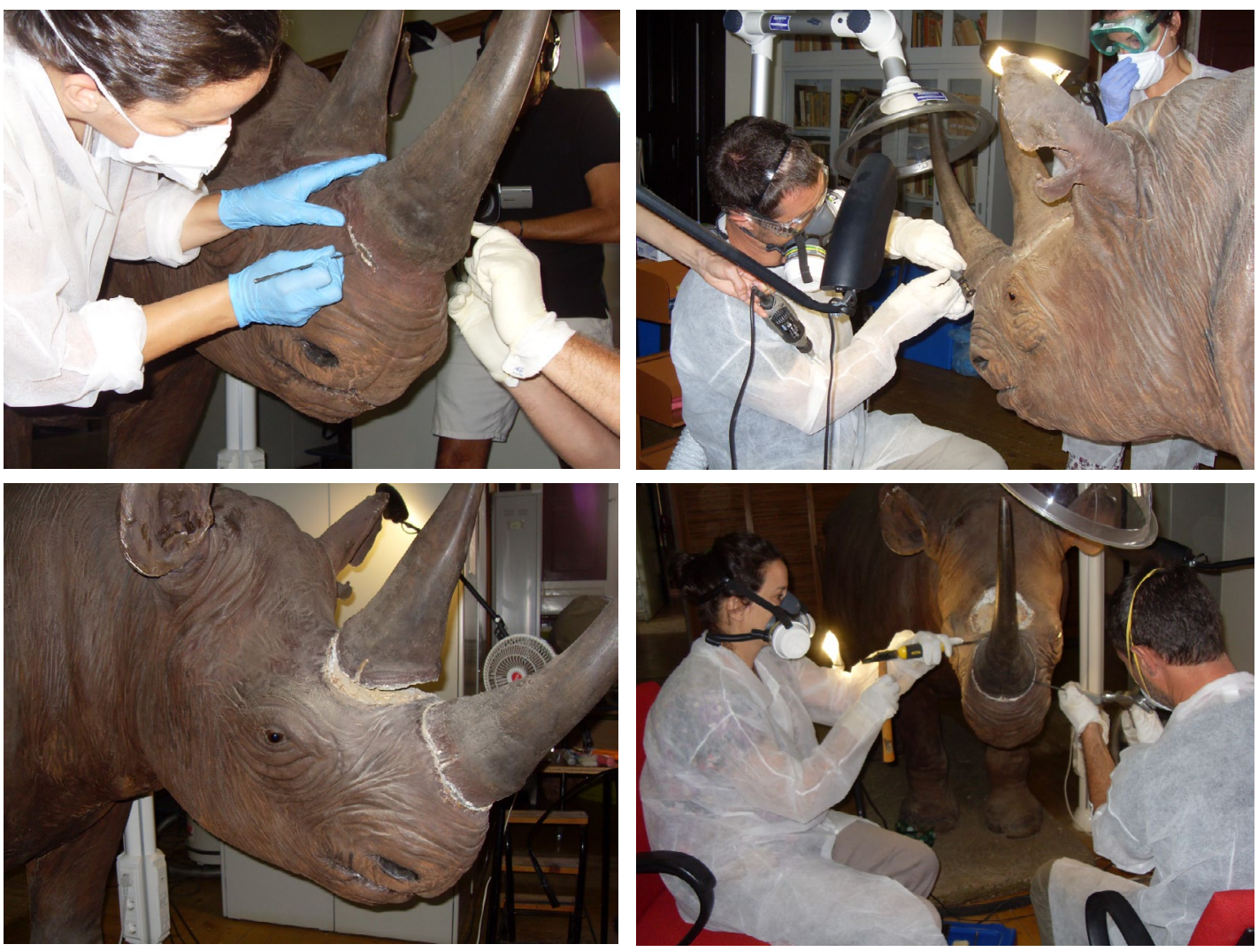

Figure 6. Details of the beginning of the removal work of the original rhino horns by Catarina Teixeira and Pedro Andrade (photos: MUHNAC archives, 2016). 
despite no apparent sustainable function at the time.

In the second stage, the objective was to mechanically remove the mortar layer between the skin and the base of the two horns, in order to reach the assembling nails and the wooden manikin head. This proved difficult because the mortar was very strong, tight and perfectly preserved. Its removal was only possible with a Dremel tool, chisels, screwdrivers, and hammers. Cutting pliers and hacksaw blades were also used to sever the nails, with the support of magnifying work-lamps and fixed vacuum cleaners (Figure 6). The first four nails removed were thinner and along the edge of the skin and horn, but the second group - another four, with similar orientation - were thicker and found deeper inside the wood.
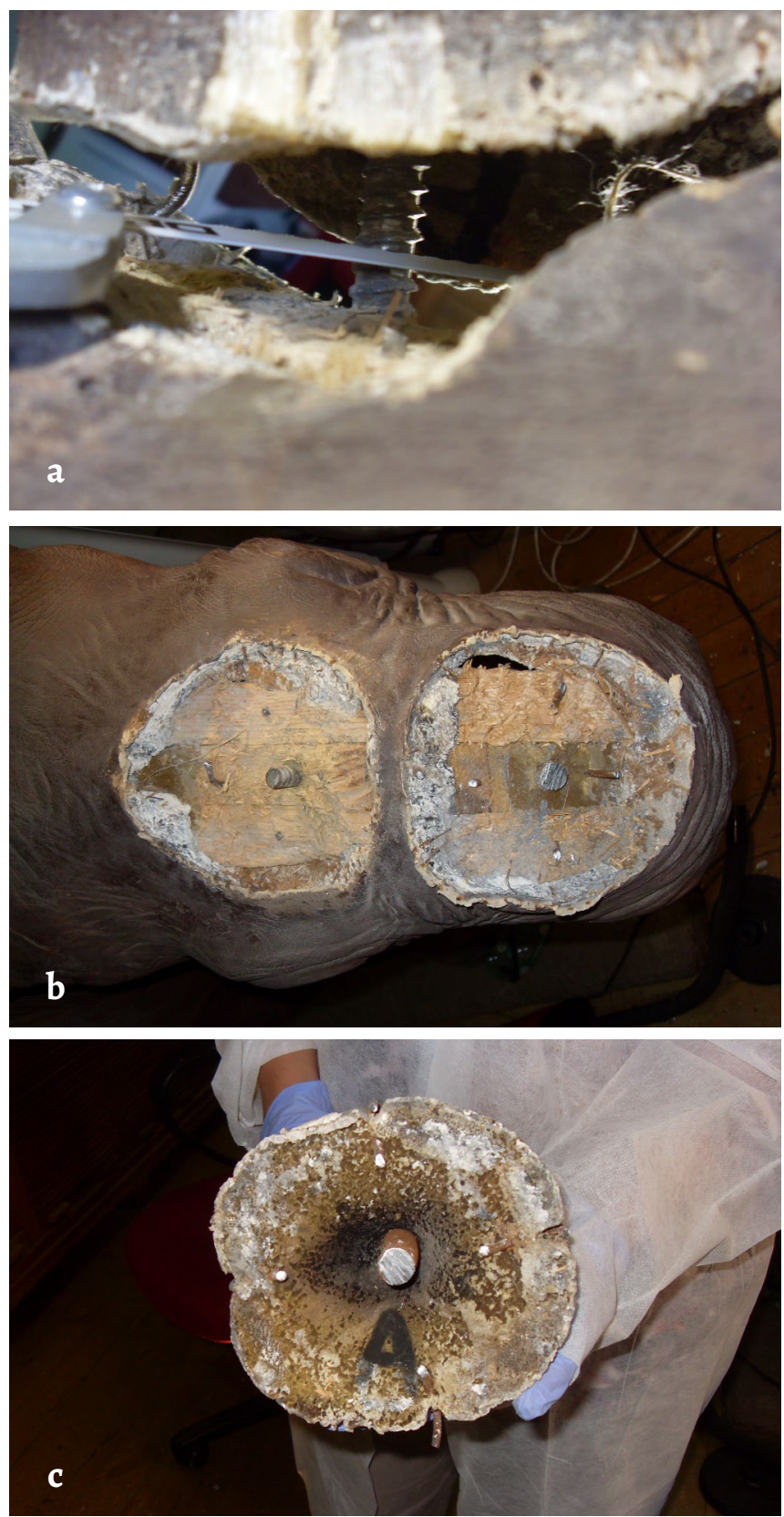

Figure 7. Detail of cutting the deepest and central nail with a hacksaw blade (a); from the base of the wooden manikin head where the horns were fixed (b); and detail of the base of one of the horns after its removal, showing the capital letter 'A' (c) (photos: MUHNAC archives, 2016).
At this point, the horns needed to be carefully and slowly pulled upwards to better reach the nails underneath without causing any damage. The inner nails were found to be wider and the central nail (which was the primary horn attachment) was also the deepest, with approximately $1 \mathrm{~cm}$ in diameter. The attachment system was similar in both horns. A capital letter A was found inscribed on the base of each horn, although it significance remains yet unknown (Figure 7). After removal, the horns were cleaned with soft brushes, identified, dated, and securely stored, together with all fragments and original material. To prevent any release of vapour, gases or infestations, particularly near the skin, the holes left in the specimen remained covered with Tyvek tissue until the attachment of the replicas.

Some of the materials collected during the removal were further analysed. Three samples from the mortar removed between the preserved skin, the base of the horns and the wooden manikin head structure were analysed with X-ray diffraction (XRD) and proton-induced X-ray emission ( $\mu$ PIXE) techniques. These analyses were conducted in November of 2016 at the Department of Engineering and Nuclear Sciences, Instituto Superior Técnico, University of Lisbon, in the context of a course addressing the use of nuclear analytical techniques for the compositional characterisation of cultural heritage. One of the samples (Figure 8) was selected for cross-analysis in both techniques, with the purpose of determining composition, particularly the presence of arsenic.

The XRD results [62] of the mortar confirmed the presence of bassanite (common plaster of Paris), gypsum, calcite, and a small quantity of quartz (Figure 9), meeting some of the composite materials of the mounting process of the specimen

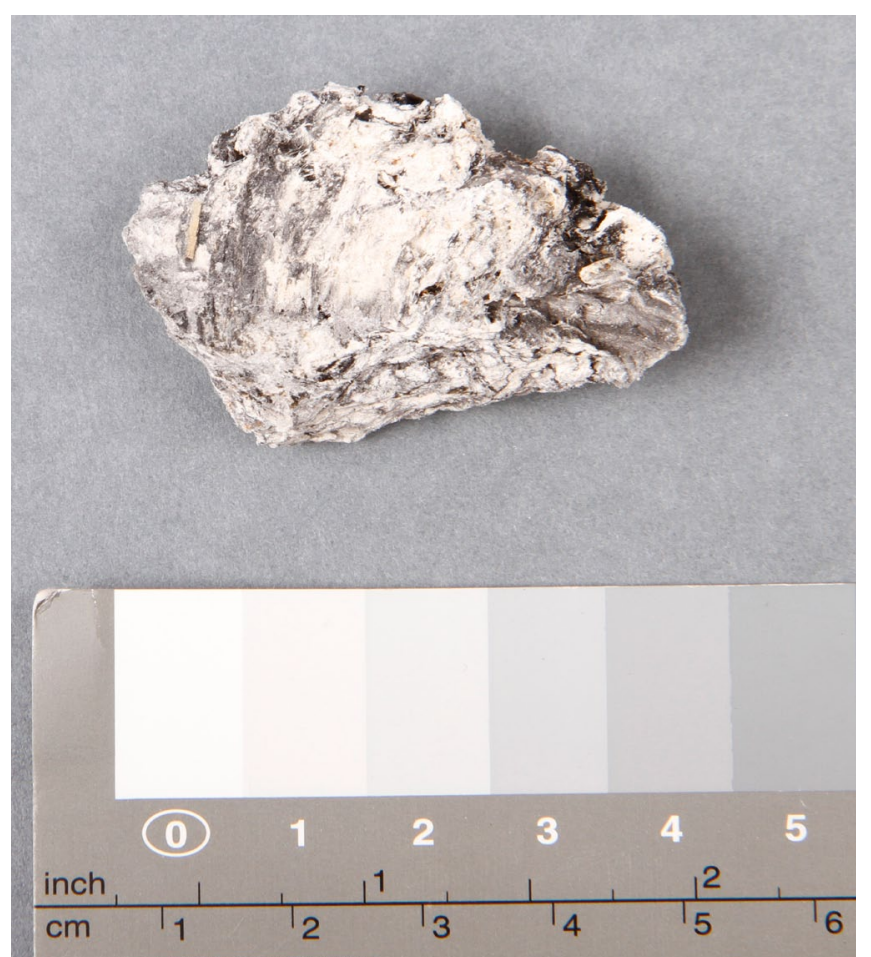

Figure 8. Detail of the mortar sample ('Corno 1_Am. 2') analysed by XRD . 


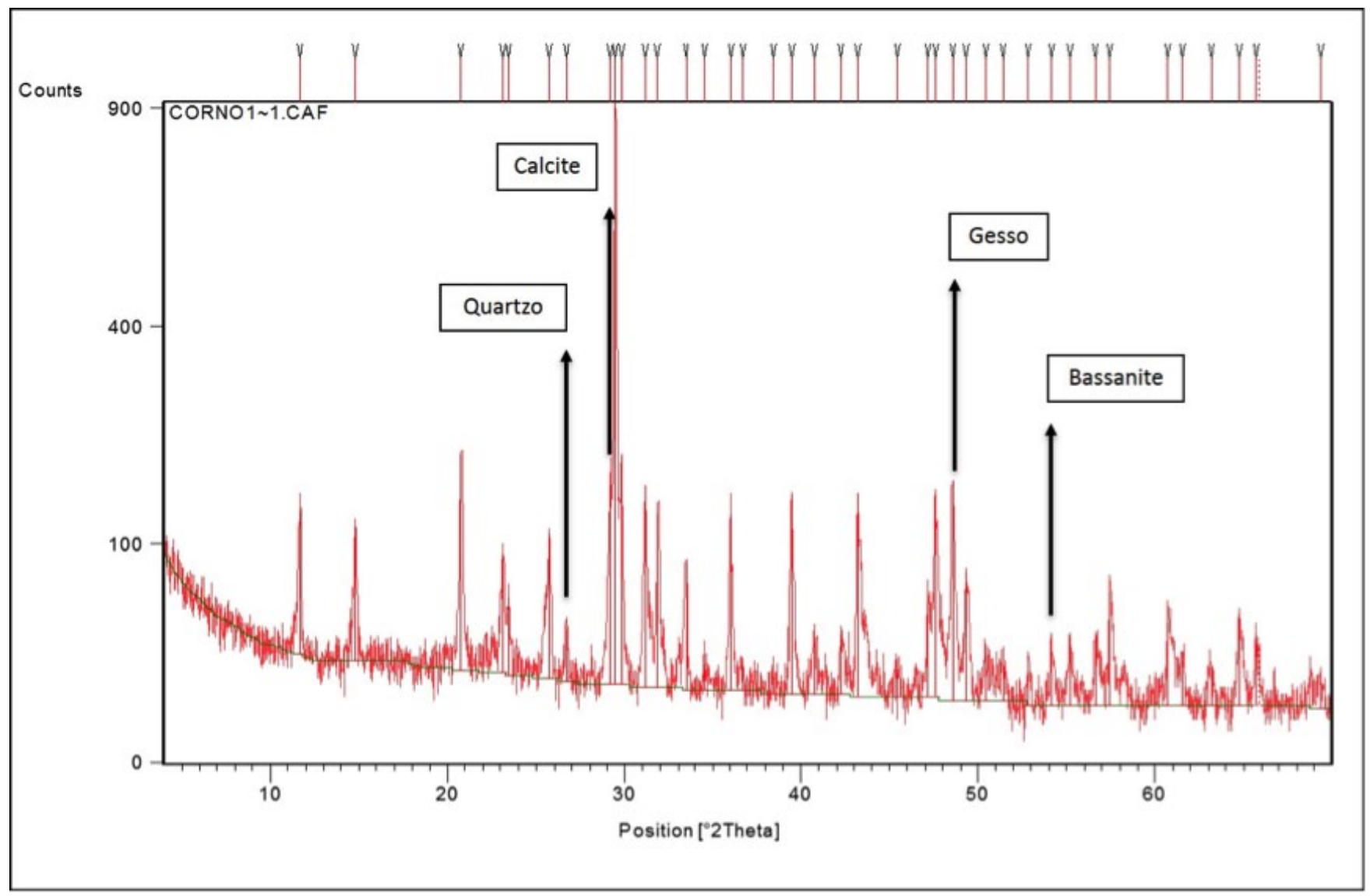

Figure 9. XRD diffractogram of the mortar sample in Figure 8 (CTN-IST/University of Lisbon) (Quartzo: quartz; gesso: gypsum).

described by Morris [58, p. 89] and Ward [59, pp. 16-31], namely plaster of Paris, and papier maché. From the $\mu$ PIXE analyses, we could infer that there was no relevant presence of arsenic on the mortar, consistent with the preparation of mammals described in 1880 by Ward [59, pp. 16-31], although further analyses will need to be completed, since this specimen is from the mid-2oth century. With more expression, we have obtained calcium that matches with the XRD analyses; data also implied the presence of sulphate, calcium carbonate, and aluminosilicate, probably concerned with a subcutaneous layer of clay used during mounting [58, p. 89]. Confirmation of the latter requires further analyses and data comparison between the two analytic techniques with more samples, in order to better understand its presence and origin [63].

\section{The moulds and casts}

The established guidelines for the intervention determined two decisions regarding the rhino horn replicas. On the one hand, they should be as exact as possible to prevent visual distortion or disruption. On the other hand, the replicas should be clearly and unequivocally identified as such for ethical reasons - the introduction of a fake element and the legibility of the intervention - and for security reasons - to prevent theft. Therefore, the word REPLICA would be added to each side of the replicas, again like in Norfolk.
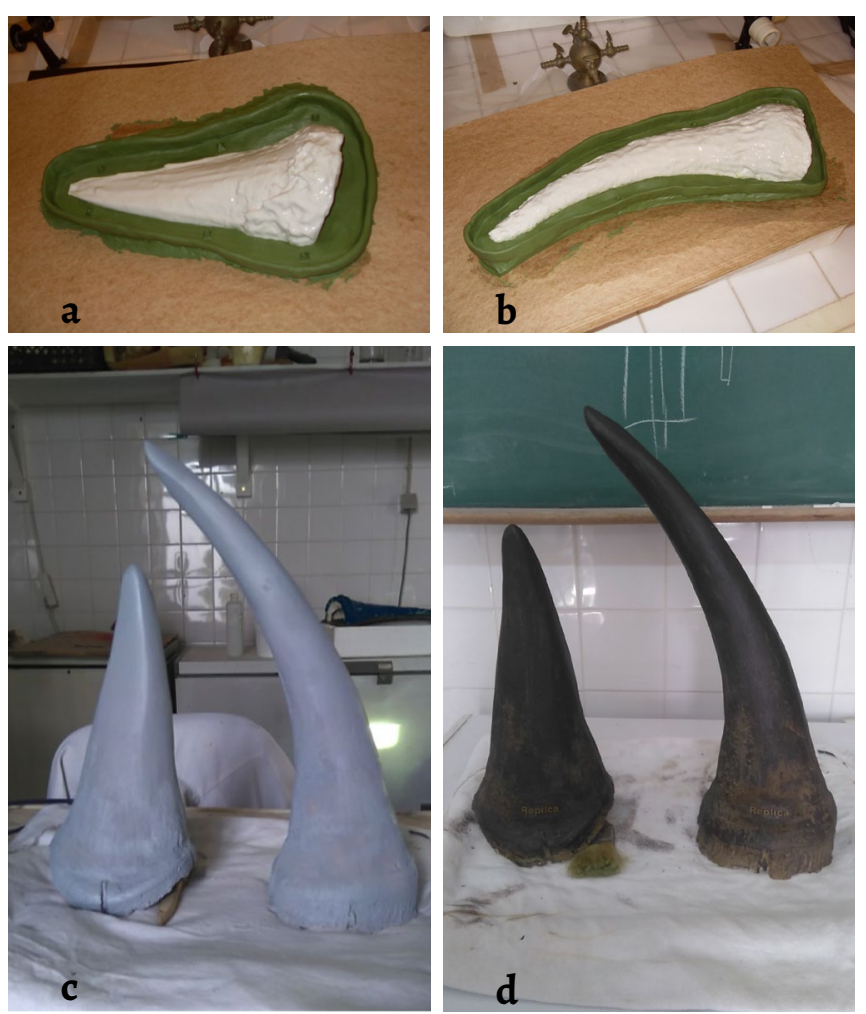

Figure 10. Details of the moulds, support moulds (a-b) and finished horn replicas (c-d) created by Pedro Andrade (MUHNAC). 
The first step in any replica building is to create the moulds. In this case, the original horns were covered with a finely spread initial layer of Elastosil M 4514 silicone [64]. The process was repeated for four days to obtain a relatively thick layer and provide solidity to the mould.

For support, an outer mould for each horn was made by using polyester resin [65]. The first step included the application of a Plasticine lip dividing each silicone mould into two parts (Figure 10). With this rim created, two first layers of polyester resin were applied into one of the halves of the mould, followed by a third layer with fibreglass [66] to add strength, and finished with a fourth layer of the same resin covering the entire mould surface. The second half of the support mould was created using the same technique as already described, except that a release agent was applied using polyvinyl alcohol BÜFA 741-0052 between the rims, in order to avoid sticking [67].

Once the two halves of the outer support moulds were completely cured, one of the halves was removed. Before removing the second half, the silicone was cut in two parts with extreme care to avoid damage to the original horn. A soft suture was made in the silicone along the flap of the remaining half of the support mould using a scalpel. Finally, the support moulds and the internal silicone moulds were gently released from the original horns. These were mechanically cleaned and would only be used again during this process for colourmatching tests.

After the moulds, the second step was to construct the replicas with Jesmonite $\mathrm{AC}$ 100, a two-component system of acrylic polymer and water-based mineral resin [68]. A thin layer of Jesmonite was placed on the surface of the moulds, followed by two more layers that catalysed after 24 hours each. The halves of the replicas were also attached with Jesmonite. After 24 hours, more Jesmonite was applied inside the replicas to provide additional support, particularly around the junction areas. The joins of the replica surface were then repaired with Apoxie Sculpt putty, a two-part system of sculpting clay and epoxy adhesive [69].

For the inscriptions, a small tablet made of Plasticine with the word REPLICA was cast in Elastosil M 4514. The mould was replicated four times in a two-component rigid polyurethane resin Polyol + Isocyanate 9190/HT16 [70] and, before the catalysing process was concluded, it was adapted to the curvilinear shape of the horn replicas. The four small tablets were then fixed on each side (Figure 10), using polyurethane resin. Finally, a primary dye (water-based) was applied both to the inscription and the replica itself, and the colouring process was performed according to the colours and shades of the real horns, using acrylic dyes with brushes and an airbrush.

The third step consisted of attaching the replicas to the rhino specimen. This was done with two layers of Apoxie Sculpt putty: the first to cover the entire section of the wooden manikin where the horns had previously been, and the second to bond the replicas to the manikin. These were firmly tied to each other for two days using cotton tying tape for solid attachment and correct positioning. Subsequently, the joints between the skin and the replica horns were homogenised using an outside ring of the aforementioned putty, applied with a spatula, and gently completed with a pattern sculpted using a needle and sponge. The colouring process also included acrylic dyes applied with soft brushes and blended with the colour of the replica horns, thus leaving the whole intervention perfectly discernible (Figure 11).
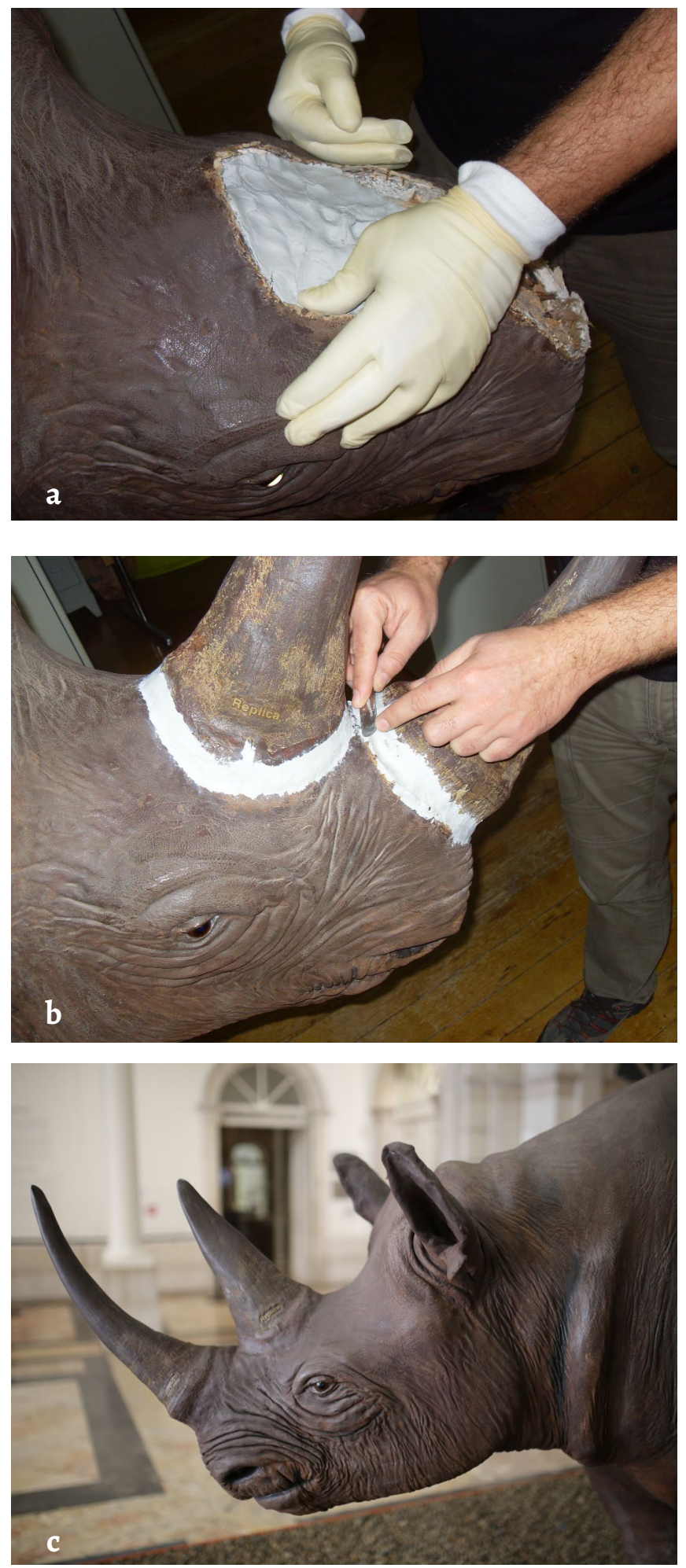

Figure 11. Detail of the attachment of the replica horns onto the specimen $(a-b)$ and the specimen after the intervention and on display at MUHNAC (photo C. Garcia, 2018) (c). 


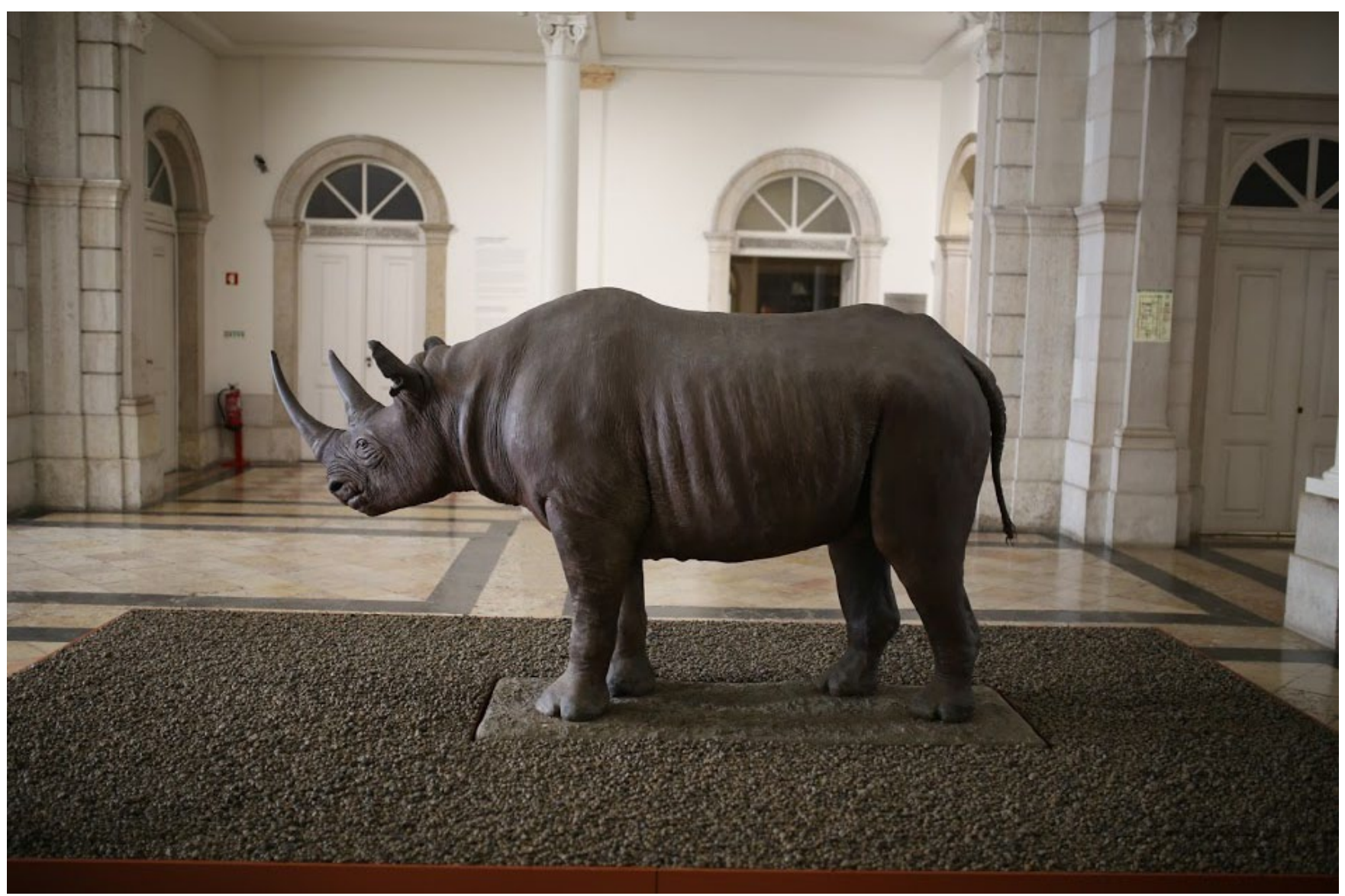

Figure 12. Specimen on display at MUHNAC (photo: C. Garcia, 2018).

The choice of fixing the replicas to the specimen only using the ring of Apoxie Sculpt putty was deliberate. On the one hand, it respects the guidelines establishing the minimal and reversible nature of the intervention, as in general the whole replica procedure was intended to create the least damage possible to the original material [46, p. 2]. So, no new holes were made and no new metallic elements or adhesives were introduced. On the other hand, the replicas are much easier to remove than the original horns, facilitating conservation monitoring, an eventual replacement and other museum functions, including education. Furthermore, in the event of an inexperienced thief trying to steal the replicas, damage associated with any removal attempt would be minimal [71].

\section{Concluding remarks}

In 2016 the conservation and taxidermy teams of MUHNAC removed the original horns from a female specimen of black rhinoceros Diceros bicornis in its collections and replaced them with clearly identified replicas. The specimen is presently on long-term display (Figure 12).

At the beginning of the decision-making process, we realised from the little feedback we received, that the removal of original horns from taxidermy rhino mounts was relatively undocumented, perhaps due to security reasons. Even in museums and conservation communities in Portugal - with the exception of those targeted and mentioned above - this seemed to be a relatively unfamiliar issue. Direct contacts that derived from our personal research proved more effective as a source of information, but as previously referred to, dedicated literature was scarce.

The intervention performed in Lisbon generated considerable internal discussion about pros and cons, ethics and technical procedures. In-depth research regarding ethical issues, best practices in similar cases, and archival research into the history of the specimen played a paramount role in to the final decision.

Several lessons have been learned with this intervention and experience.

The first lesson is, naturally, the importance of sound research for the accomplishment of best practices on conservation and restoration, regarding ethical standards and principles.

The second is the establishment of clear criteria and guidelines in advance, as well as methods that can be shared and used by the community of conservators, conservatorrestorers, taxidermists and museums abroad.

The third is the benefit of interdisciplinary teamwork: firstly, reaching out to our network of colleagues (including Norfolk) and ultimately the sharing of technical knowledge and new approaches; secondly, through the bridges built 
between two different worlds, traditions, and training, of conservators and taxidermists - a crucial partnership in the conservation of this type of heritage.

The fourth is how off the radar this type of interventions is from mainstream conservation professionals and, more generally, how off the radar scientific collections and the heritage of science is from mainstream cultural heritage.

And finally, further research needs to be done, including:

i) to clarify both rhinos' history since their arrival in Lisbon and their preservation before MUHNAC. Further research could be accomplished by cross-referencing documentation from other Portuguese institutional archives (namely, AGU archive), but particularly from the IICT's historical archives. Ward's company archives should be worth contacting also;

ii) to collect more precise documentation regarding the juvenile rhino specimen - currently in need of restoration namely the mounting and previous restoration treatments; these, complemented with analytical and imaging techniques, should contribute to our better understanding of both specimens' history, materiality, and conservation.

Both i) and ii) could not be done with the desired detail at the time of the adult rhino horns' replacement due to several reasons, including exhibition deadlines.

Although visitors were deliberately kept away from the intervention described in this paper for reasons already explained, we recognise that the procedure provides an extraordinary educational opportunity for audiences of all ages in the context of rhino extinction and nature conservation. Documentation collected will enable the museum to explore these opportunities in the near future.

Museums have the responsibility to preserve cultural heritage for future generations - and oftentimes to explore intricate issues as a response to social and cultural challenges and questions - but also to continue to make them accessible and displayed for a wider public.

\section{Acknowledgements}

The authors would like to thank Ana Campos, Branca Moriés, Catarina Mateus, César Garcia, Marta Costa, Marta Lourenço, João Santos and Rogério Abreu (MUHNAC, University of Lisbon); Jonathan Clark (Conservator, Norfolk Museums Service); Isabel Dias and Luís Alves (Campus Tecnológico e Nuclear, Instituto Superior Técnico, University of Lisbon); Nigel Larkin and Simon Moore (Natural History Conservation), Nigel Monaghan (National Museum of Ireland), Vítor Gens (Lisbon City Council Archive), Catarina Gonçalves (Conservator-restorer freelancer) and Pat Morris (taxidermy history expert). Laura Moura is working at MUHNAC thanks to a research grant provided by the Portuguese Foundation for Science and Technology (FCT/SFRH/BI/135098/2017). This paper benefited from the use of the Portuguese Infrastructure of Scientific Collections (PRISC.pt) (POCI-01-0145FEDER-022168).

\section{REFERENCES}

1. Viscardi, P., 'The horns of a dilemma: the impact of the illicit trade in rhino horn', NatSCA News 22 (2012) 8 13, http://www.natsca.org/article/107.

2 Pleasance, C., 'Dozens of rhinos died so someone could buy these 'trophies': Record $£ 12$ million haul of rhinoceros horn is seized in Malaysian airport destined for Vietnamese 'health trade" (2018-08-20), in Mail Online, https://www.dailymail. co.uk/news/article-6079177/50-rhino-horns-worth-12m-seizedMalaysia-airport-bound-Vietnam.html (accessed 2018-9-1).

3 Lourenço, M. C.; Eiró, A., 'O Museu de Ciência', in Património da Universidade de Lisboa: Ciência e Arte, ed. M. C. Lourenço \& M. J. Neto, Tinta-da-china / Universidade de Lisboa, Lisboa (2011) 35-54.

4 Póvoas, L.; Lopes, C. I; Melo, I; Correia, A. I.; Alves, M. J.; Cardoso, H.; Galopim, A. M. G.,'O Museu Nacional de História Natural', in Património da Universidade de Lisboa: Ciência e Arte, ed. M. C. Lourenço \& M. J. Neto, Tinta-da-china / Universidade de Lisboa, Lisboa (2011) 17-34.

5 Felismino, D., Saberes, Natureza e Poder. Colecções Científicas da Antiga Casa Real Portuguesa, Caleidoscópio, Casal de Cambra (2014).

6 'Decreto-Lei n. ${ }^{\circ} 141 / 2015$ de 31 de julho', Diário da República-1. ${ }^{a}$ série (148) (2015-7-31), 5185-5188.

7 Lobato, A., Da Comissão de Cartographia ao Instituto de Investigação Científica Tropical (1983-1983). Memória Histórica, Instituto de Investigação Científica Tropical, Lisboa (1983).

8 Grove, L; Thomas, S., "The rhino horn on display has been replaced by a replica": museum security in Finland and England', Journal of Conservation and Museum Studies 14 (1), 1-11, https://doi.org/10.5334/jcms.124.

9 Gao, Y.; Stoner, K. J.; Lee, A. T. L.; Clark, S. G., 'Rhino horn trade in China: an analysis of the art and antiques maret', Biological Conservation 201 (2016) 343-347,

https://doi.org/10.1016/j.biocon.2016.08.001.

10 Nowell, K., 'Species trade and conservation. Rhinoceroses: Assessment of rhino horn as a traditional medicine', report for the CITES Secretariat SC62 Doc. 47.2 Annex (Rev.2) (2012), http://www.rhinoresourcecenter.com/index.php? s=1\&act=pdf viewer\&id=1389957235\&folder $=138$ (accessed 2019-6-11).

11 'Europol and Ireland identify organised crime group active in illegal trading of rhino horn - Press release' (2011-7-7), Europol, https:// www.europol.europa.eu/newsroom/news/europoland-ireland-identify-organised-crime-group-active-in-illegaltrading-of-rhino-horn (accessed 2018-9-1).

12 Hewitt, D., 'How the high price of rhino horn fuels European museum thefts' (2012-7-1), The Star, https://www.thestar.com/ news/world/2012/07/01/how_the_high_price_of_rhino_horn_ fuels_european_museum_thefts.html (accessed 2018-9-1).

13 'Rhinoceros horn stockpiles - a serious threat to rhinos' (201108-31), Humane Society International, https://www.hsi.org/ wp-content/uploads/assets/pdfs/rhino_horn_stockpiles_ report.pdf (accessed 2018-6-1).

14 'Fact sheet: rhino horn museum heists' (2011-7-20), in Culture Heritage Law, Lawyers' Committee for Cultural Heritage Preservation, https://www.culturalheritagelaw.org/ rhinofactsheet (accessed 2018-9-1).

15 Woolfoot, A., 'Cirencester auctioneer Chris Surfleet escapes jail sentence after admitting rhino horn theft' (2009-12-11), in Wilts and Gloucestershire Standard, https:// www.wiltsglosstandard.co.uk/news/4790435.cirencesterauctioneer-chris-surfleet-escapes-jail-sentence-afteradmitting-rhino-horn-theft/ (accessed 2018-9-1).

16 Landes, D., 'Swedish museum hit by rhino horn heist' (20117-27), The Local, https://www.thelocal.se/20110727/35186 (accessed 2018-9-1). 